\title{
Coping strategies, concerns, and habits of Brazilian men in the COVID-19 context
}

\author{
Estratégias de enfrentamento, preocupações e hábitos de homens brasileiros no contexto da pandemia da COVID-19
}

Estrategias de afrontamiento, preocupaciones y hábitos de los hombres brasileños en el contexto de la pandemia de COVID-19

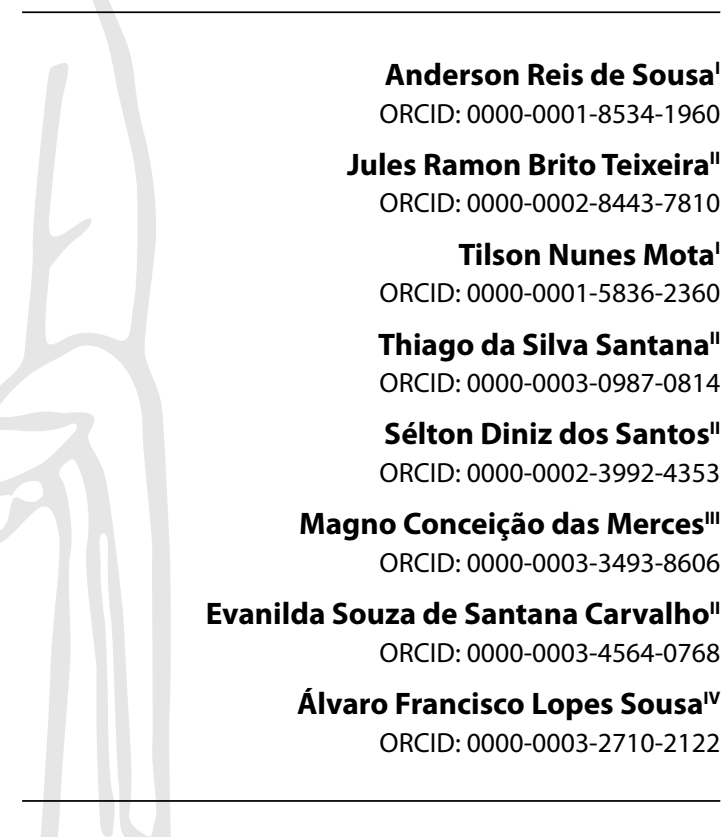

'Universidade Federal da Bahia. Salvador, Bahia, Brazil. "Universidade Estadual de Feira de Santana. Feira de Santana, Bahia, Brazil.

I' Universidade do Estado da Bahia. Salvador, Bahia, Brazil. " Universidade de São Paulo, Ribeirão Preto, São Paulo, Brazil.

How to cite this article: Sousa AR, Teixeira JRB, Mota TN, Santana TS, Santos SD, Merces MC, et al. Coping strategies, concerns, and habits of Brazilian men in the COVID-19 context. Rev Bras Enferm. 2021;74(Suppl 1):e20210040. https://doi.org/10.1590/0034-7167-2021-0040

Corresponding author:

Anderson Reis de Sousa

E-mail: anderson.sousa@ufba.br

EDITOR IN CHIEF: Dulce Barbosa ASSOCIATE EDITOR: Hugo Fernandes

\section{ABSTRACT}

Objective: To describe coping strategies, concerns and habits of Brazilian men during the COVID-19 pandemic. Method: Cross-sectional, descriptive and nationwide study, carried out in 2020 with a total of 1015 men living in Brazil. A descriptive statistic was used. Results: Young (41.2\%), black (61.4\%), highly educated (66.8\%), high income (33.2\%), living with family/ friends (49.7\%) and formal workers (65.6\%) predominated. As coping strategies predominated: exclusive use of the private health system (36.4\%), support from family/friends (78.2\%) and leisure (97.7\%) and domestic activities (64.9\%). Social distancing (59.7\%), economic (58.0\%) and work situations (44.4\%) were the main reasons for concern. Among the prevention/ control attitudes, hand washing $(94.3 \%)$ and social distancing (91.0\%) prevailed. Media consumption (84.6\%) and health risk (65.4\%) were the main increased habits. Conclusion: Brazilian men adopted coping strategies recommended by health authorities, with concerns and habits of potential risk to physical and mental health.

Descriptors: Pandemics; COVID-19; Men; Strategies; Habits.

\section{RESUMO}

Objetivo: Descrever estratégias de enfrentamento, preocupações e hábitos de homens brasileiros durante a pandemia da COVID-19. Método: Estudo transversal, descritivo e de abrangência nacional, que foi realizado em 2020 com 1.015 homens residentes no Brasil. Empregou-se estatística descritiva. Resultados: Predominaram jovens $(41,2 \%)$, negros $(61,4 \%)$, com alta escolaridade $(66,8 \%)$, alta renda $(33,2 \%)$, residentes com familiares/ amigos(as) $(49,7 \%)$ e trabalhadores formais $(65,6 \%)$. Como estratégias de enfrentamento predominaram: uso exclusivo do sistema privado de saúde $(36,4 \%)$, suporte de familiares/ amigos(as) $(78,2 \%)$ e atividades de lazer $(97,7 \%)$ e domésticas (64,9\%). Distanciamento social $(59,7 \%)$, situações econômica $(58,0 \%)$ e de trabalho $(44,4 \%)$ foram os principais motivos de preocupação. Dentre as atitudes de prevenção/controle prevaleceram a lavagem das mãos $(94,3 \%)$ e o distanciamento social $(91,0 \%)$. Consumo de mídias $(84,6 \%)$ e de risco à saúde $(65,4 \%)$ foram os principais hábitos aumentados. Conclusão: Homens brasileiros adotaram estratégias de enfrentamento recomendadas pelas autoridades sanitárias, com preocupações e hábitos de potencial risco à saúde física e mental.

Descritores: Pandemias; COVID-19; Homens; Estratégias; Hábitos.

\section{RESUMEN}

Objetivo: Describir estrategias de afrontamiento, preocupaciones y hábitos de los hombres brasileños durante la pandemia de COVID-19. Método: Se trata de un estudio transversal, descriptivo y de alcance nacional, llevado a cabo en 2020 mediante estadística descriptiva entre 1.015 hombres residentes en Brasil. Resultados: Predominaron los jóvenes $(41,2 \%)$, negros $(61,4 \%)$, con estudios superiores $(66,8 \%)$, ingresos altos $(33,2 \%)$, que vivían con familiares/amigos (49,7\%) y tenían trabajo formal $(65,6 \%)$. Como estrategias de afrontamiento predominaron: el uso exclusivo del sistema sanitario privado (36,4\%), el apoyo de la familia/ amigos $(78,2 \%$ ) y las actividades de ocio $(97,7 \%)$ y domésticas $(64,9 \%)$. Las situaciones de distancia social $(59,7 \%)$, económica $(58,0 \%$ ) y laboral $(44,4 \%)$ fueron los principales motivos de preocupación. Entre las actitudes de prevención/control, predominaron el lavado de manos $(94,3 \%)$ y el distanciamiento social $(91,0 \%)$. Los hábitos de consumo de medios sociales $(84,6 \%)$ y de riesgo para la salud $(65,4 \%)$ aumentaron considerablemente. Conclusión: Los hombres brasileños adoptaron las estrategias de afrontamiento recomendadas por las autoridades sanitarias, con preocupaciones y hábitos de riesgo potencial para la salud física y mental. Descriptores: Pandemias; COVID-19; Hombres; Estrategias; Hábitos. 


\section{INTRODUCTION}

COVID-19, a pandemic caused by the SARS-CoV-2 virus (Severe acute respiratory syndrome coronavirus 2 ), behaves as the greatest health challenge of the 21 st century. Although the statistics are devastating in the world, particularly in Brazil the maintenance of high numbers of new cases and deaths is of great concern ${ }^{(1)}$. Until January 9, 2021, Brazil was already in the third position worldwide in number of cases and deaths. In this country, up to the same date, 8075998 cases and 202631 deaths were registered by COVID-19, which makes the daily epidemic complex and dramatic ${ }^{(2-3)}$.

The pattern of distribution of cases is not homogeneous between different genders or age groups ${ }^{(4)}$. In Italy, seven out of ten deaths are men, whereas in Brazil this scenario is in the proportion of six in ten deaths ${ }^{(5)}$. From the analysis of laboratory tests of about 179 thousand people tested for COVID-19 in Brazil, Brazilian researchers identified that the infection in individuals aged 13 to 60 years old predominated among men. Men and older adults are at greater risk of evolving to severe conditions, and consequently to death, which needs greater attention from health professionals, as well as the reworking of the production of Nursing Care ${ }^{(6)}$.

So far, there is no robust evidence regarding the determinants of COVID-19 morbidity and mortality in the male population, although factors associated with lifestyle ${ }^{(7)}$, delay in seeking health services and even sexual behaviors have been identified as related to the occurrence of disease. For this reason, an important knowledge gap is seen in Brazilian and international literature on the subject. Furthermore, it reveals the expressive need to understand the factors that generate vulnerability of men in the pandemic context, which implies guidelines for the production of health and nursing care ${ }^{(8)}$, which justifies the performance of this study.

\section{OBJECTIVE}

To describe coping strategies, concerns and habits of men living in Brazil in the context of the COVID-19 pandemic.

\section{METHOD}

\section{Ethical aspects}

The research was developed considering the ethical aspects, safeguarding anonymity, autonomy, freedom, beneficence and non-maleficence in all stages. For this purpose, the research project was approved by the Research Ethics Committee. The Informed Consent Form was offered in digital format and it was only after the electronic signature that the filling of the form was released through the online platform and free access.

\section{Design, study setting and period}

Cross-sectional, descriptive study carried out through a virtual environment, with men living in Brazil. In order to guarantee the accuracy, quality, reliability and transparency in the description of the study, the recommendations of the Strengthening the Reporting of Observational Studies in Epidemiology (STROBE) were adopted. The study was conducted between March and May 2020, that is, during the period of social distancing that was determined by health authorities in most parts of the country due to the COVID-19 pandemic.

\section{Sampling and eligibility criteria}

A total of 1015 men living in Brazil, with a cisgender, transgender and non-binary gender identity participated. The inclusion criteria were being an adult, literate men, with access to the internet, aged 18 or over. Men traveling internationally in Brazil were excluded.

\section{Study protocol}

Data collection took place through an electronic form on a free digital platform made available by Google Forms. Research participants were invited by sharing the link with the form via digital social media (Facebook, Instagram and WhatsApp).

The structured form was composed of thematic blocks to assess: 1-Sociodemographic characteristics (age, race/skin color, education, monthly income, living with) and occupational (work situation and employment relationship); 2- Aspects related to pandemic coping strategies (use of the health system, type of support during the pandemic and strategies to make coping easier); 3- Reasons for concern, attitudes and habits adopted during the pandemic. To guarantee the quality of the study, the Reporting of Observational Studies in Epidemiology (STROBE) was fulfilled.

\section{Data analysis}

The Statistical Package for the Social Sciences software, version 23.0, was used for data analysis Absolute and relative frequencies were estimated for categorical variables and minimum and maximum values, in addition to mean and standard deviation (SD) for quantitative variables with normal distribution.

\section{RESULTS}

A total of 1015 men living in Brazil were interviewed. Most were homosexuals (47.7\%), aged between 18 and 29 years old (41.2\%) (Min: 17 and Max.: 75; : 33.3 e SD: \pm 10.4 ), blacks (61.4\%), higher education $(66.8 \%)$, income of five minimum wages or more $(58.1 \%)$, those who lived with family/friends (49.7\%), workers (72.5\%) and formal employment relationship (65.6\%) (Table 1). It was evident that 212 (20.9\%) were students and 22 (2.2\%) were retired (data not shown in the table).

With regard to the characteristics related to coping with the pandemic and reasons for concern, to make the coping with the COVID-19 pandemic easier, most men reported using exclusively the private health system (36.4\%), lack of support for coping with the pandemic $(62.1 \%)$ and, of those who had support, the main source was family and/or friends (78.2\%). Most men adopted some type of strategy to face the pandemic (97.9\%) and the ones that predominated most were leisure (97.7\%) and domestic activities (64.9\%). Among the concerns, social distancing (59.7\%), economic situation (58.0\%) and work situation (44.4\%) were the 
most mentioned. Regarding the concerns experienced by men, there were attitudes towards prevention and control of infection with the new coronavirus, with evidence for hand washing (94.3\%) and social distancing (91.0\%). The low adherence to the use of protective masks (23.6\%) stands out (Table 2 ).

Considering daily habits of life that were carried out before the pandemic, most men reported an increase in at least one type of behavior (95.9\%). Among these habits, there was a significant increase in the consumption of media (84.6\%) and health risk behaviors (65.4\%). Most did not stock food (65.4\%) and adopted new health care habits (81.1\%). (Table 3$)$.

Table 1 - Distribution of men according to sociodemographic and occupational characteristics, Brazil, 2020 ( $\mathrm{N}=1015)$

\begin{tabular}{|c|c|c|}
\hline Variables & $\mathbf{n}$ & $\%$ \\
\hline \multicolumn{3}{|c|}{$\begin{array}{l}\text { Sociodemographic and occupational characteristics } \\
\text { Sexual identity }\end{array}$} \\
\hline Heterosexual & 435 & 42.9 \\
\hline Bisexual & 84 & 8.3 \\
\hline Homosexual & 484 & 47.7 \\
\hline Others & 12 & 1.2 \\
\hline \multicolumn{3}{|l|}{ Age range } \\
\hline 18 to 29 years old & 418 & 41.2 \\
\hline 30 to 39 years old & 370 & 36.5 \\
\hline 40 or more & 227 & 22.4 \\
\hline \multicolumn{3}{|l|}{ Race/color } \\
\hline Not black & 392 & 38.6 \\
\hline Black & 623 & 61.4 \\
\hline \multicolumn{3}{|l|}{ Education } \\
\hline Elementary school & 66 & 6.5 \\
\hline High school & 271 & 26.7 \\
\hline Higher education & 678 & 66.8 \\
\hline \multicolumn{3}{|c|}{ Monthly income (in minimum wages)* } \\
\hline Up to 1 & 208 & 20.5 \\
\hline 1 to 2 & 237 & 23.3 \\
\hline 3 to 4 & 233 & 23.0 \\
\hline 5 or more & 337 & 33.2 \\
\hline \multicolumn{3}{|l|}{ Living with } \\
\hline Family/friends & 504 & 49.7 \\
\hline Partner/Children & 297 & 29.3 \\
\hline Alone & 514 & 21.1 \\
\hline \multicolumn{3}{|l|}{ Working situation } \\
\hline Working & 736 & 72.5 \\
\hline Not working & 279 & 27.5 \\
\hline \multicolumn{3}{|c|}{ Working relationship ( $\mathrm{N}=736)$} \\
\hline Formal & 483 & 65.6 \\
\hline Informal & 253 & 34.4 \\
\hline
\end{tabular}

Table 2 - Distribution of men according to characteristics related to coping with the pandemic and reasons for concern, Brazil, $2020(\mathrm{~N}=1015)$

\begin{tabular}{lcc}
\hline Health system use (N=978) & & \\
$\quad$ Exclusively SUS & 367 & 36.2 \\
$\quad$ Exclusively Private System & 369 & 36.4 \\
$\quad$ SUS and Private System & 242 & 23.8 \\
$\quad$ & & \\
Support for coping with the pandemic & 385 & 37.9 \\
$\quad$ Yes & 630 & 62.1 \\
$\quad$ No & & \\
Type of support for coping with the pandemic ( $\mathrm{n}=385)$ & 53 & 13.7 \\
$\quad$ Health Service & 76 & 19.7 \\
$\quad$ Security and/or Public Administration & 55 & 14.3 \\
Religion/Spirituality & 301 & 78.2 \\
$\quad$ Family and/or Friends & 30 & 3.0 \\
$\quad$ Others & \multicolumn{2}{c}{ To be continued }
\end{tabular}

Table 2 (concluded)

Reason(s) for concern

$\begin{array}{llll}\text { No } & 38 & 3.7\end{array}$

$\begin{array}{lll}\text { Yes } & 977 & 96.3\end{array}$

Type of concern $(n=977)$

$\begin{array}{lll}\text { Physical appearance } & 127 & 13.0\end{array}$

Distancing from contact/social life $\quad 583 \quad 59.7$

Lack of leisure $\quad 270 \quad 27.6$

$\begin{array}{lll}\text { Lack of physical activity } & 417 & 42.7\end{array}$

$\begin{array}{lll}\text { Sexual inactivity } & 342 & 35.0\end{array}$

Economic situation $\quad 567 \quad 58.0$

Educational situation $\quad 337 \quad 34.5$

Family situation $\quad 338 \quad 34.6$

$\begin{array}{lll}\text { Working situation } & 434 & 44.4\end{array}$

$\begin{array}{lll}\text { Situation of loving relationship } & 131 & 13.4\end{array}$

$\begin{array}{lll}\text { Emotional situation } & 399 & 40.8\end{array}$

$\begin{array}{lll}\text { Adoption of strategies to make coping easier } & 994 & 97.9\end{array}$

$\begin{array}{lcc}\text { No } & 21 & 2.1\end{array}$

Types of strategy to make coping easier
Domestic activities

$\begin{array}{lll}\text { Leisure activities } & 971 & 97.7\end{array}$

$\begin{array}{lll}\text { Physical activities } & 313 & 31.5\end{array}$

$\begin{array}{lll}\text { Working activities } & 490 & 49.3\end{array}$

Prevention/control attitudes

$\begin{array}{lll}\text { Quarantine } & 735 & 72.4\end{array}$

$\begin{array}{lll}\text { Social distancing } & 924 & 91.0\end{array}$

$\begin{array}{lll}\text { Handwashing } & 957 & 94.3\end{array}$

$\begin{array}{lll}\text { Body hygiene } & 790 & 77.8\end{array}$

$\begin{array}{lll}\text { Food hygiene } & 637 & 62.8\end{array}$

$\begin{array}{lll}\text { Household hygiene } & 661 & 65.1\end{array}$

Use of hand sanitizer $\quad 794 \quad 78.2$

$\begin{array}{lll}\text { Use of masks } & 240 & 23.6\end{array}$

Note: SUS: Unified Health System - Sistema Único de Saúde.

Table 3 - Distribution of men according to increased habits during the pandemic, Brazil, $2020(\mathrm{~N}=1015)$

\begin{tabular}{lcc}
\hline Increased habits during the pandemic & & \\
$\quad$ No & 42 & 4.1 \\
Yes & 973 & 95.9 \\
Increased habits during the pandemic $(\mathrm{n}=973)$ & & \\
$\quad$ Media consumption & 823 & 84.6 \\
$\quad$ Family life & 395 & 40.6 \\
$\quad$ Leisure/health & 613 & 63.0 \\
Health risk behaviors (alcohol and other drugs) & 636 & 65.4 \\
Stocking food & & \\
$\quad$ No & 664 & 65.4 \\
Yes & 351 & 34.6 \\
Adoption of new health care habits & & \\
$\quad$ Yes & 884 & 81.1 \\
No & 131 & 12.9 \\
\hline
\end{tabular}

\section{DISCUSSION}

This is the first Brazilian study to raise substantial data on the ways of male experiences regarding the use of coping strategies, in addition to the characteristics of the concerns raised and the habits developed since the advent of the pandemic in the country where they live, which makes this innovative study.

The findings of this study showed the adoption of coping strategies recommended by the health authorities, which confirmed, in high prevalence, the emergence of male mobilizations to deal in a combative way in face of the disruptive phenomena caused and imposed by the pandemic and obtained recreational and domestic aspects in its composition. Furthermore, the results showed characteristics related to behavior and health control existing in the reasons that led men to raise concerns in the 
face of the pandemic. The exercise of health care practices was noteworthy, which are based on the prevention and control of infection and viral transmission based on the insertion of sanitary measures recommended by the authorities, despite the reduced adherence to some of them, this in the period in which men were investigated. Furthermore, the findings showed the establishment of new habits adopted and incorporated into daily life by men living in Brazil, and this fact occurred in high prevalence after the advent of the COVID-19 pandemic. Among the habits adopted by the men, those aimed at consumption stood out, in this case, the media, and focused on the use of health risk behaviors, such as the use of alcohol and other drugs.

A relevant aspect to be analyzed about the COVID-19 pandemic is the social determination of the disease, as social conditions have played a significant influence on people's attitudes towards coping with the disease, as well as the emergence of concerns and fears ${ }^{(9)}$. And this occurs especially in men $^{(10)}$, which in addition to having the highest rates of infection, complications due to the disease, for example, the Severe Acute Respiratory Syndrome, hospital admissions and deaths ${ }^{(3)}$, has expressed more clinical and behavioral outcomes unfavorable when compared to women $^{(4,11-14)}$. It is relevant to emphasize that this study points out in its results expressive social markers regarding the analysis of male behavior in health and, in this case in particular, the health and disease process, both related to SARS-CoV2 and COVID-19. This provides an important epidemiological and social basis for the clinical understanding and socio-cultural phenomena of men in the context of the pandemic, information that can be consumed by professionals in Nursing, health and related areas.

Thus, it was found that the sample investigated is young, a marker that may generate greater vulnerability to infection and to the spread of SARS-CoV2. The literature indicates that among the younger population, adherence to disease control measures has been lower ${ }^{(15)}$. Therefore, unfavorable clinical outcomes are observed in relation to COVID-19, such as the increase in the number of new cases and the impacts on mental health. In addition, the fact that younger men are more likely to adopt/maintain health risk habits, such as abusive consumption of alcohol and other drugs, in addition to smoking ${ }^{(12,15)}$, which makes them even more vulnerable to outcomes unfavorable to health during social isolation, which is necessary in the pandemic period.

The most prevalent race/color among the men investigated was black, which includes black and brown individuals. Race/color is an important marker of analysis of the pandemic phenomenon, especially due to the expressive marks of structural racism in force in the country where the research was carried out. During the pandemic, both in Brazil and in other countries, black and brown men are the most vulnerable to COVID-19, as well as the difficulty in accessing health care ${ }^{(16-17)}$. It is worth mentioning that during the advance of COVID-19 around the world, outbreaks of racism, stigma and xenophobia were amplified in the communities, compromising the psychosocial well-being and the right to dignity, life and citizenship of these people $e^{(18-19)}$.

Most men had an income of five minimum wages or more, possibly configuring themselves as middle and upper middle class. However, about $20 \%$ of the sample is composed of men who live with only one minimum wage, which shows the disparities that exist in facing the pandemic. Brazil is a country where there is a high concentration of income, accentuating social inequities, with the wealthiest population having the most access to health services, the highest level of education and the best living resources. In contrast, people with lower incomes often live in unfavorable social conditions, which points to the reflection of the markers that generate social inequalities related to COVID-19 ${ }^{(20)}$ on the need to target actions focused on their social and health demands.

The prevalent sexual identity among the participants in this study was homosexual, which requires a look at the vulnerabilities that are overlapping in this population group, strongly crossed by disparities in access to rights and weaknesses in socio-affective support networks, such as family. Thus, during the COVID-19 pandemic it has been identified that the LGBTQIA + population, especially among gay men (men who have sex with other men) has been more vulnerable to having their psychological wellbeing affected ${ }^{(21-22)}$.

When analyzing who the men lived with, the findings showed living with family/friends during the pandemic, which may result in greater protection against the impacts of social isolation on people's mental health, culminating in the maintenance of satisfactory rates of psychosocial well-being ${ }^{(23)}$, as well as in the development of positive attitudes and effective and healthy coping strategies ${ }^{(24)}$. In this regard, it was identified that one in four of the respondents lived alone, a situation that may disadvantage healthy coping with the pandemic, making them more susceptible to loneliness, that is: romantic in having no one to share their emotions with, prolonged boredom experience, the inaccessibility to the socioaffective network, the difficulty in handling decision conflicts and confinement ${ }^{(25-26)}$. This is an issue that is ambiguous and relevant. The LGBTQIA + population usually experiences family conflicts related to their sexual orientation. In this context of the COVID-19 pandemic, due to the measures of social distancing, gay men started to spend more time at home, therefore, home and family life may not necessarily be a friendly and healthy environment for them, emphasizing the psycho-emotional suffering for facing intense pressure from the family for their non-heterosexuality ${ }^{(27)}$.

Regarding the reasons that generated concerns among men during the COVID-19 pandemic in Brazil, it was found that physical appearance, distance from social contact, lack of leisure, lack of physical activity, sexual inactivity, the economic, family, work, love and emotional relationships are the most expressive. However, the social distancing, the situations, both economic and work, were more evident. This reflects the current Brazilian scenario, which is facing a serious budget crisis that joins the new phenomena caused by COVID-19. In this scenario, it is emphasized that the abrupt disruptions in daily relations and in the maintenance of the productive workforce, which were caused by the pandemic, have had a deleterious impact on psychosocial well-being ${ }^{(28-29)}$.

In countries such as Bangladesh, India and Colombia, COVID-19 has had a serious impact on the mental health of the population, with a high rate of suicide, especially among men ${ }^{(30-31)}$. The construction of masculinities, loss of ability to work, difficulty in subsistence, abrupt reduction in income, weaknesses in social security, changes in daily life and in the situation of occupational health are elements that must be valued, since they are issues related to the outbreak of negative emotions and feelings among 
men, which is also influenced by personal belief systems ${ }^{(10,32-33)}$.

In relation to strategies for coping with the pandemic, most men reported having leisure and domestic activities. The pandemic and social isolation imputed changes in the population's routine in general, added to the significant impacting changes in the mental health situation ${ }^{(34)}$. With the greater availability of time, there was a greater investment in leisure activities and domestic work. Many families, due to the need for protection, ended up dismissing domestic workers and started to assume these functions. These activities became central and re-signified people's routines, which could be strategies for reducing anxiety and psychological distress ${ }^{(35)}$. As an example, in Spain, being a man and practicing leisure activities was associated with less anxiety and depression symptoms ${ }^{(34)}$.

The babelic scenario, which emerged in Brazil and in the world as a result of the pandemic, has demanded from men attitudes and behaviors to make coping easier and prevent situations harmful to physical and psycho-emotional integrity. It is challenging, in a country with such social inequality and territorial extension, to develop effective individual and collective coping strategies. Even so, a joint effort was evidenced, through changes in daily behavioral styles due to the imposed social isolation, to minimize the consequences caused by social confinement. It should be noted that in a period of social confinement, the population trends, in the short or long term, to present a sedentary lifestyle, which favors body overweight and the appearance of comorbidities associated with greater cardiovascular risk ${ }^{(35)}$, as well as psychosocial disorders such as anxiety and depression ${ }^{(31)}$. Nursing workers are responsible for implementing interventions with a focus on reducing degrading impacts, especially on the physical and mental health of this public ${ }^{(19-20)}$.

Restrictions on social contact due to the COVID-19 pandemic increased levels of stress and feelings of anxiety in the general population. As a result, media consumption has been increasing substantially, corroborating the results of this study, and has been observed in most countries around the world, since it is the option accessible to most people to minimize the deleterious impacts on mental health, expanding the possibilities of social interactions. However, the problematic use of certain online applications, even as an alternative to compensate for negative feelings and stress, can culminate in hypervigilance and anxiety, especially among men - who are more likely to increase the consumption of games and erotic platforms. This change in the consumption of media can represent a risk for mental disorders or can be considered a functional phenomenon and limited in time, requiring longitudinal monitoring to produce more robust evidence ${ }^{(36)}$.

Most men established as social attitudes towards coping with the pandemic social distancing and positive behavior, considering that evidence has reinforced that the restriction of social contact is the basis for the prevention and efficient control of the spread of the virus, which significantly reduces the mass transmissibility to the population ${ }^{(33-34)}$. Social isolation, combined with isolation of cases, is essentially effective ${ }^{(37)}$, which reinforces the importance of health professionals and services to encourage the adoption of this strategy to confront COVID-19.

Countries such as Singapore, South Korea and Japan recorded successful experiences, as they adopted early measures such as social distancing, in addition to showing that the immediate implementation of these recommendations, in line with rigorous case management and mass diagnoses, positively influenced the course of transmissibility, resulting in a lower morbidity and mortality rate due to COVID-19(38-39).

With regard to effective methods of prevention and control to reduce the progress and spread of SARS-CoV-2, recommended by the Ministry of Health of Brazil and in line with the WHO, converging the fact that most men have adopted personal care practices, such as hand hygiene with soap and water and/or $70 \%$ sanitizer, body hygiene, food and household hygiene, and the use of masks. These measures for the prevention of contamination are recommended based on evidence that has emerged through experience in previous epidemics in the world ${ }^{(37)}$. Therefore, the pandemic event can be seen as a trigger for potentialities for self-care, mobilizing men to give more attention and, consequently, to exercise self-care practices.

However, It is noteworthy that of all the effective measures to avoid contagion, with regard to the use of masks, there was low adherence by men, which may be involved in different dimensions, such as factors of human behavior, self-perception of invulnerability, difficulties in accessing the acquisition, discredit and/or denial of the disease, underestimation of individual responsibility, habits and cultural belief systems that reflect the resistance of men in adopting the recommended protective measures and even the creation of safe strategies for coping ${ }^{(31-32)}$

It is important to note that it is already known that the use of the mask associated with social distancing is highly effective in coping with the disease. There is evidence that the chance of transmission of the virus is $2.6 \%$ in people who maintained a physical distance of one meter or more. At a distance of less than one meter, the risk of contagion reaches $12.8 \%$. Regarding facial masks, the same study found that the correct use can also result in a great reduction in the risk of infection, with $3.1 \%$ of chances of contagion with the use of protection, against $17.4 \%$ in people who did not use the mask. Therefore, it appears that this attitude is liable to change, considering the period of data collection, as well as the positive data regarding the adherence to other coping strategies. As knowledge about the disease advances, as well as interventions by health professionals and the media, it can promote greater awareness of the importance and effectiveness of using masks to control and reduce the spread of COVID-19(40).

\section{Limitations of the study}

This study has limitations related to the cross-sectional design adopted, making it impossible to establish cause/effect. The data collection in a virtual environment also limited the analysis of the phenomenon only to the population with the most favorable socioeconomic situation, excluding men who did not have access to digital technologies and who were possibly experiencing difficulties in effectively adhering to the strategies for coping with the pandemic.

\section{Contributions to Health and Nursing}

The findings of this study contribute substantially to the advancement of scientific knowledge and practice in health and nursing in the face of the pandemic context, especially with regard to the 
way it has affected the male population. The data may serve as a basis for structuring strategic, contingent and programmatic actions, both during and in the post-pandemic period. In addition, it constitutes an important subsidy for the advancement of the implementation of the National Policy for Attention to Men's Health.

\section{CONCLUSION}

Finally, it was identified that men adopted as the main coping strategies the exclusive use of the private health system, the support of family/friends and the practice of leisure and domestic activities. The reasons for concern involved the restriction of social interaction, both economic and work situations. In addition, attitudes towards prevention/control showed adherence to social distancing, hand washing and use of $70 \%$ sanitizer. Still, there was an increase in habits related to the consumption of media and health risk behaviors. Thus, Brazilian men adopted coping strategies recommended by health authorities, with concerns and increased habits with potential risk to physical and mental health.

\section{REFERENCES}

1. Albuquerque LP, Silva RB, Araújo RMS. COVID-19: origin, pathogenesis, transmission, clinical aspects and current therapeutic strategies. Rev Prev Infec Saúde [Internet]. 2020[cited 2020 Jun 20];6:10432. Available from: https://revistas.ufpi.br/index.php/nupcis/article/view/10432/ pdf_1

2. Bastos LS, Niquini RP, Lana RM, Villela DAM, Cruz OG, Coelho FC, Codeço CT, Gomes MFC. COVID-19 and hospitalizations for SARI in Brazil: a comparison up to the 12th epidemiological week of 2020. Cad Saude Publica. 2020;(22):36(4):e00070120. https://doi. org/10.1590/0102-311X00070120

3. Ministério da Saúde (BR). Boletim epidemiológico especial: Doença pelo Coronavírus COVID-19 - número 45. Brasília. [Internet]. 2020[cited 2020 Jun 20]. Available from: https://www.gov.br/saude/pt-br/media/pdf/2021/janeiro/15/boletim_epidemiologico_COVID_45.pdf

4. Zeng F, Dai C, Cai P, Wang J, Xu L, Li J, et al. A comparison study of SARS-CoV-2 IgG antibody between male and female COVID-19 patients: a possible reason underlying different outcome between sex. J Med Virol. 2020;92(10):2050-54. https://doi.org/10.1002/jmv.25989

5. Onder G, Rezza G, Brusaferro S. Case-Fatality rate and characteristics of patients dying in relation to COVID-19 in Italy. JAMA. 2020;323(18):1775-6. https://doi.org/10.1001/jama.2020.4683

6. Figueredo WN, Macêdo TTS, Cardoso GMP, Fernandes ETBS. Bibliometric analysis of Brazilian production on COVID-19. Rev Baiana Enferm. 2020;34:e37107. https://doi.org/10.18471/rbe.v34.37107

7. World Health Organization (WHO). Coronavirus disease (COVID-19) pandemic [Internet]. 2020 [cited 2020 Jun 20]. Available from: https:// www.who.int/emergencies/diseases/novel-coronavirus-2019

8. Silva FV. Enfermagem no combate à pandemia da COVID-19. Rev Bras Enferm. 2020;73(Suppl 2):e2020sup2. https://doi. org/10.1590/0034-7167-202073suppl201

9. Oliveira AC, Lucas Coaglio T, Iquiapaza R. What has the COVID-19 pandemic taught us about adopting preventive measures? Texto Contexto Enferm. 2020;29:e20200106. https://doi.org/10.1590/1980-265x-tce-2020-0106

10. Sousa AR, Carvalho ESS, Santana TS, Sousa AFL, Figueiredo TFG, Escobar OJV, et al. Men's feelings and emotions in the Covid-19 framing. Ciênc Saúde Coletiva. 2020;25(9):3481-91. https://doi.org/10.1590/1413-81232020259.18772020

11. Conti P, Younes A. Coronavirus COV-19/SARS-CoV-2 affects women less than men: clinical response to viral infection. J Biol Regul Homeost Agents. 2020;34(2):339-43. https://doi.org/10.23812/Editorial-Conti-3

12. Bwire GM. Coronavirus: why men are more vulnerable to Covid-19 than women? SN Compr Clin Med. 2020;2:874-8. https://doi.org/10.1007/ s42399-020-00341-w

13. Rozenberg S, Vandromme J, Martin C. Are we equal in adversity? does Covid-19 affect women and men differently? Maturitas. 2020;138:6268. https://doi.org/10.1016/j.maturitas.2020.05.009

14. Griffith DM, Sharma G, Holliday CS, Enyia OK, Valliere M, Semlow AR, et al. Men and COVID-19: a biopsychosocial approach to understanding sex differences in mortality and recommendations for practice and policy interventions. Prev Chronic Dis. 2020;17:200247. https://doi. org/10.5888/pcd17.200247

15. Efuribe C, Barre-Hemingway M, Vaghefi E, Suleiman BA. Coping with the COVID-19 crisis: a call for youth engagement and the inclusion of young people in matters that affect their lives. J Adolesc Health. 2020;67(1):16-7. https://doi.org/10.1016/j.jadohealth.2020.04.009

16. Lassale C, Gaye B, Hamer M, Gale RG, Battyc D. Ethnic disparities in hospitalisation for COVID-19 in England: the role of socioeconomic factors, mental health, and inflammatory and pro-inflammatory factors in a community-based cohort study. Brain Behav Immun. 2020;88:44-9. https://doi.org/10.1016/j.bbi.2020.05.074

17. Ballard D, Laborde D, Noriaki Y, Jahromi, AH, Hamidianjahromi A. Why African Americans Are a Potential Target for COVID-19 Infection in the United States. J Med Internet Res. 2020;22(6):e19934. https://doi.org/10.2196/19934

18. Dubey S, Biswas P, Ghosh R, Chatterjee S, Dubey MJ, Chatterjee S, et al. Psychosocial impact of COVID-19. Diabetes Metab Syndr. 2020;14(5):779-88. https://doi.org/10.1016/j.dsx.2020.05.035 
19. Santos MPA, Nery JS, Goes EF, Silva A, Santos ABS, Batista LE, Araújo EM. População negra e Covid-19: reflexões sobre racismo e saúde. Estudos Avançados.2020;34(99):225-44. https://doi.org/10.1590/s0103-4014.2020.3499.014

20. Estrela FM, Soares CFS, Cruz MA, Silva AF, Santos JRL, Moreira TMO, et al. Covid-19 Pandemic: reflecting vulnerabilities in the light of gender, race and class. Ciênc Saúde Coletiva. 2020;25(9):3431-3436. https://doi.org/10.1590/1413-81232020259.14052020

21. Carvalho HEF, Schneider G, Sousa AR, Camargo ELS, Nunes RV, Possani MA, et al. Suspected COVID-19 flu-like syndrome in men who have sex with men and have been involved in casual sex. Rev Bras Enferm. 2020;73(suppl 2):e20200913. https://doi.org/10.1590/0034-7167-2020-0913

22. Sousa ÁFL, Queiroz AAFLN, Lima SVMA, Almeida PD, Oliveira LB, Chone JS, et al. Chemsex practice among men who have sex with men (MSM) during social isolation from COVID-19: multicentric online survey. Cad Saude Publica. 2020;36(12):e00202420. https://doi. org/10.1590/0102-311X00202420

23. Sanchez TH, Zlotorzynska M, Rai M, Baral SD. Characterizing the impact of COVID-19 on men who have sex with men across the United States in April, 2020. AIDS Behav. 2020;1-9. https://doi.org/10.1007/s10461-020-02894-2

24. Brown SM, Doom JR, Lechuga-Peña S, Watamura SE, Koppelsa T. Stress and parenting during the global COVID-19 pandemic. Child Abuse Negl. 2020:104699. https://doi.org/10.1016/j.chiabu.2020.104699

25. Prime H, Wade M, Browne DT. Risk and resilience in family well-being during the COVID-19 pandemic. Am Psychol. 2020;75(5):631-43. https://doi.org/10.1037/amp0000660

26. Suen YT, Chan RCH, Wong EMY. Effects of general and sexual minority-specific COVID-19-related stressors on the mental health of lesbian, gay, and bisexual people in Hong Kong. Psychiatry Research, 2020;292(113365):1-7. https://doi.org/10.1016/j.psychres.2020.113365

27. Sousa AR, Queiroz AM, Florencio RMS, Portela PP, Fernandes JD, Pereira A. Homens nos serviços de atenção básica à saúde: repercussões da construção social das masculinidades. Rev Baiana Enferm. 2016;30(3):1-10. http://dx.doi.org/10.18471/rbe.v30i3.16054

28. Banerjee D, Rai M. Social isolation in Covid-19: The impact of loneliness. Int J Soc Psychiatr. 2020;66(6):525-7. https://doi. org/10.1177/0020764020922269

29. Mamun MA, Griffiths MD. First COVID-19 suicide case in Bangladesh due to fear of COVID-19 and xenophobia: possible suicide prevention strategies. Asian J Psychiatr 2020;51:102073. https://doi.org/10.1016/j.ajp.2020.102073

30. Goyal K, Chauhan P, Chhikara K, Gupta P, Singh MP. Fear of COVID 2019: first suicidal case in India! Asian J Psychiatr 2020;49:101989. https:// doi.org/10.1016/j.ajp.2020.101989

31. Gonzalez-Diaz JM, Cano JF, Pereira-Sanchez V. Psychosocial impact of COVID-19-related quarantine: reflections after the first case of suicide in Colombia. Cad Saúde Pública. 2020;36(6):e00117420. https://doi.org/10.1590/0102-311X00117420

32. Ferreira LDL, Angelim DA, Sabóia RR, Demes CR, Carvalho CS, Noronha NFM, et al . Covid-19 in the State of Ceará: behaviors and beliefs in the arrival of the pandemic. Ciênc Saúde Coletiva. 2020;25(5):1575-86. https://doi.org/10.1590/1413-81232020255.07192020

33. Sousa AR. How can COVID-19 pandemic affect men's health? a sociohistoric analysis. Rev Prev Infec Saúde. 2020;6:10549. https://doi. org/10.26694/repis.v6i0.10549

34. Sousa AR, Santana TS, Moreira WC, Sousa ÁFL, Carvalho ESS, Craveiro I. Emoções e estratégias de coping de homens à pandemia da COVID-19 NO BRASIL. Texto Contexto Enferm. 2020;29:e20200248. https://doi.org/10.1590/1980-265x-tce-2020-0248

35. Aquino EML, Silveira IH, Pescarini JM, Aquino R, Souza-Filho JA, Rocha AS, et al . Medidas de distanciamento social no controle da pandemia de COVID-19: potenciais impactos e desafios no Brasil. Ciênc Saúde Coletiva. 2020;25(Suppl-1):2423-46. https://doi. org/10.1590/1413-81232020256.1.10502020

36. Lemenager T, Neissner M, Koopmann A, Reinhard I, Georgiadou E, Müller A, et al. COVID-19 lockdown restrictions and online media consumption in Germany. Int J Environ Res Public Health. 2021;18(1):14. https://doi.org/10.3390/ijerph18010014

37. Fullana M, Mazzei-Hidalgo D, Vieta E, Radua E. Coping behaviors associated with decreased anxiety and depressive symptoms during the COVID-19 pandemic and lockdown. J Affect Disord. 2020;275:80-81. https://doi.org/10.1016/j.jad.2020.06.027

38. Ferreira Jr M, Irigoyen MC, Consolim-Colombo F, Saraiva JFK, Angelis K. Vida fisicamente ativa como medida de enfrentamento ao COVID-19. Arqui Bras Cardiol. 2020;114(4):601-2. https://doi.org/10.36660/abc.20200235

39. Cluver L, Lachman JM, Sherr L, Wessels I, Krug E, Rakotomalala S, et al. Parenting in a time of COVID-19. Lancet. 2020;395:e64. https://doi. org/10.1016/S0140-6736(20)30736-4

40. Bezerra ACV, Silva CEM, Soares FRG, Silva JAM. Fatores associados ao comportamento da população durante o isolamento social na pandemia de COVID-19. Ciênc Saúde Coletiva. 2020;25(Suppl-1):2411-21. https://doi.org/10.1590/1413-81232020256.1.10792020 